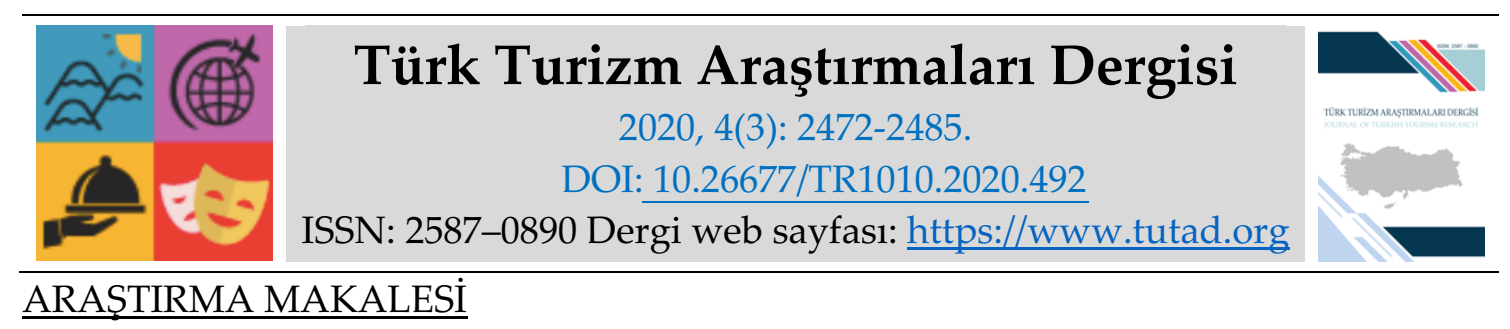

\title{
Destinasyon Kavramının Yeniden Yapılandırılması Üzerine Düşünsel Bir İnceleme*
}

Dr. Ceyhun AKYOL, Artvin Çoruh Üniversitesi, Artvin Meslek Yüksekokulu, Artvin, e-posta: ceyhunakyol@artvin.edu.tr ORCID: https://orcid.org/0000-0001-5542-7309

Prof. Dr. Burhanettin ZENGIN, Sakarya Uygulamalı Bilimler Üniversitesi, Turizm Fakültesi, Sakarya, e-posta: bzengin@subu.edu.tr ORCID: https://orcid.org/0000-0002-6368-0969

Öz

Birtakım turistik faaliyetleri içeren ve turizm kaynaklarına yön veren destinasyon kavramı ile ilgili ulusal ve uluslararası literatürde farklı biçimlerde ifadeler kullanılması söz konusudur. Sahip olduğu karmaşık yapısı ile çok yönlü bir kavram olan destinasyon, İngilizceden "destination" kelimesi temel alınarak dilimizde "destinasyon" olarak kullanılmakta olup ulusal ve ulusal literatürde yer alan yazar ve araştırmacıların çalışmalarında değişik tanımlar ve farklı kelimelerle ifade edilmeye çalışılmaktadır. Türk Dil Kurumunda "varılacak olan yer" şeklinde ifade edilen destinasyon kavramı Türkçede "turizmle ilgili alan", "turistik bölge", "ziyaret edilen yer", "turistik merkez" gibi kavramlarla ifade edilmekte olup tam karşıllı̆̆ ise ilgili literatürde kesinleşmemiş durumdadır. Bu çalışmanın amacı, ulusal ve uluslararası literatürde destinasyon kavramı ile ilgili yaşanan tanım karmaşıklığına bir nebze de olsa katkı sağlayabilmek, bir tanım önerisi geliştirmek ve ilgili literatüre katkıda bulunabilmektir. Çalışma kapsamında ikincil verilerden yararlanılmış, literatür taraması tekniği ile veri toplanmıştır. Karmaşık bir yapıya sahip olan destinasyon kavramına yönelik ulusal ve uluslararası literatürde yaşanan tanım farklılığı ve anlam karmaşasına bir tanımlama denemesiyle katkı sağlamaya çalışılmıştır.

* Bu çalışma, birinci yazarın “Doğu Karadeniz Turizminin Geliştirilmesine Yönelik Bir Araştırma: Artvin Destinasyonu Örneği” başlıklı doktora tezinden türetilmiş, Sakarya Uygulamalı Bilimler Üniversitesi Bilimsel Araştırma Projeler Koordinatörlüğü tarafından da desteklenmiştir (Proje No: 2017-60-02-008).

Anahtar Kelimeler: Destinasyon, Literatür, Tanım Denemesi.

Makale Gönderme Tarihi: 16.04 .2020

Makale Kabul Tarihi: 02.07.2020

\section{Önerilen Atıf:}

Akyol, C. ve Zengin, B. (2020). Destinasyon Kavramının Yeniden Yapılandırılması Üzerine Düşünsel Bir İnceleme, Türk Turizm Araştırmaları Dergisi, 4(3): 2472-2485.

(C) 2020 Türk Turizm Araştırmaları Dergisi. 


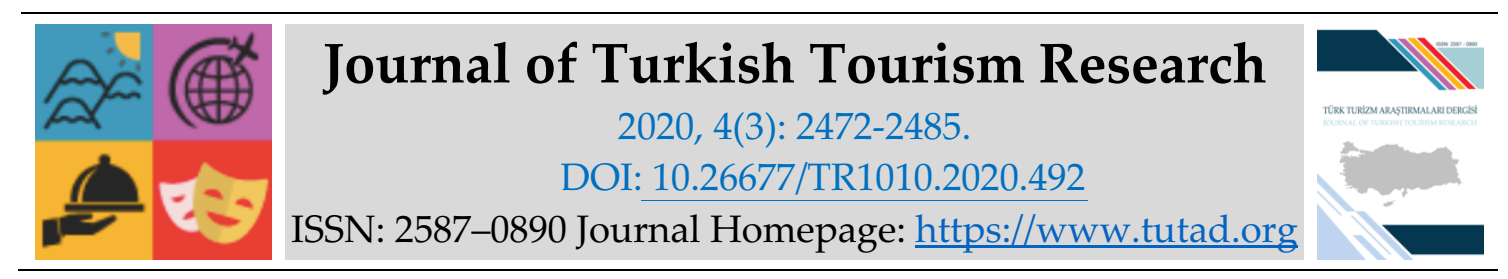

\title{
$\underline{\text { RESEARCH PAPER }}$
}

\section{An Intellectual Study on the Restructuring of the Destination Concept}

Dr. Ceyhun AKYOL, Artvin Çoruh University, Artvin Vocational School, Artvin, e-mail: ceyhunakyol@artvin.edu.tr ORCID: https://orcid.org/0000-0001-5542-7309

Prof. Dr. Burhanettin ZENGIN, Sakarya University of Applied Sciences, Faculty of Tourism, Sakarya, e-mail: bzengin@subu.edu.tr ORCID: https://orcid.org/0000-0002-6368-0969

\begin{abstract}
Different expressions are used in the national and international literature regarding the concept of destination, which includes some touristic activities and directs tourism resources. Destination, which is a versatile concept with its complex structure, is used as a "distension" in our language based on the word "distension" from English, and its tried to be expressed with different definitions and words in the studies of authors and researchers in the national and international literature. The term "destination", expressed in the Turkish Language Institution as "place to arrive", is tried to be explained with concepts such as "tourism-related area", "touristic region", place of visit", "touristic center", and its exact counterpart is uncertain in the relevant literature. The aim of this study is to contribute to the definition complexity related to the concept of destination in the national and international literature, to develop a definition proposal and to contribute to the related literature. Within the scope of the study, secondary data were used and data were collected using the literature review technique. It has been tried to contribute to the definition of destination, which has a complex structure, with an attempt to define the difference in meaning and complexity in the national and international literature.
\end{abstract}

Keywords: Destination, Literature, Definition Attempt.

Received: 16.04 .2020

Accepted: 02.07.2020

\section{Suggested Citation:}

Akyol, C. and Zengin, B. (2020). An Intellectual Study on the Restructuring of the Destination Concept, Journal of Turkish Tourism Research, 4(3): 2472-2485.

(c) 2020 Türk Turizm Araştırmaları Dergisi. 


\section{Gíriş}

Destinasyon kavramı, ulusal ve uluslararası literatürde farklı tanımlarla ifade edilmektedir. Bu durum zaman zaman anlam farklılıklarına neden olmakta, tanım karmaşası yaratabilmektedir. Oldukça kapsamlı ve birçok unsuru bünyesinde barındıran destinasyon kavramı (Şengül vd., 2018:11) kapsamının genişliği ve bileşikliği nedeniyle dünyanın birçok dilinde de aynı kelime ile tasvir edilmektedir.

Ulusal ve uluslararası literatürde destinasyon kavramının net olarak ifade edilmesinde veya tam olarak bir kelime karşılığı kullanılmasında zorluk yaşanmaktadır. Destinasyon kavramının geniş kitlelerce kullanımı, kavrama yönelik kastedilen bölge, ifade edilen alan, anlatılmak istenen yer konularındaki karışıklığı daha da artırmaktadır.

Farklı kaynaklarda değişik açılardan (turizm talebi, turizm arzı) ele alınan destinasyon kavramı, genel olarak coğrafi alan, bölge, turizm bölgesi, çekim bölgesi gibi ifadelerle birlikte kullanılmaktadır. Ulusal ve uluslararası literatürde (özellikle turizm) daha net anlam ile ifade edilebilmesi ve sahip olduğu karmaşık yapının daha net çözümlenebilmesi adına destinasyon kavramının tanımlamasında ortak bir yapı oluşturulması gerekmektedir.

\section{DESTINASYON}

Kişinin ikamet ettiği alan dışına gerçekleştirdiği ziyaret sahası olarak da ifade edilen destinasyon kavramı, ziyaretçinin olanaklarından istifade ettiği ve bir süre kullandığ fiziksel bir alan olarak da değerlendirilmektedir (Pike, 2004:3; Wang, 2011:3). Literatürde destinasyon ayrıca, yerel olarak sunumu gerçekleştirilen ürün, hizmet ve tatil birikimlerinin tamamı ya da ziyaretçilerin değişik sebeplerle yer aldığı coğrafi bir alan veya yer, bölge olarak da geçmektedir (Tinsley ve Lynch, 2001:372).

Destinasyon, yerli ve yabancı ziyaretçiler açısından doğal, kültürel ve tarihi değerleri barındıran turistik çekim yerleridir. Birçok bileşeni barındıran destinasyon kavramı ile ilgili Güncel Türkçe Sözlükte (Türk Dil Kurumu) 'varılacak olan yer' ifadesi geçmekte, ulusal ve uluslararası literatürde ise farklı tanımlarla karşılaşılmaktadır (Minghetti, 2001:256; Haugland vd., 2011:268; Türk Dil Kurumu, 2019).

Genel anlamda 'varış yeri' ifadesinin tercih edildiği turizm endüstrisinde destinasyon kavramı, yerli ve yabancı ziyaretçilerin farklı amaçlarla geçici bir süre tercih ettiği yöre, köy, kasaba, şehir, bölge, ülke hatta kıta kelimeleri yerine tercih edilmekte olup farklı çalışmalarda varış noktası, turizm bölgesi, turizm yöresi, ziyaret edilen yer, hedef bölge, turistik istasyon şeklinde de kullanılmaktadır (Lebe, 2005:1137; Vanhove, 2005:108; Akyol vd., 2018:312).

\section{YÖNTEM}

Özellikle turizm endüstrisi ile bağlantılı tanımlarda ağırlıklı olarak coğrafi temele dayandırılan destinasyon kavramına yönelik yaklaşımlar farklı gibi algılansa da ulusal ve uluslararası literatürdeki ifadeler ağırlıklı olarak birbirleri ile ilişkili görülmektedir. Çalışmanın amacı destinasyon olgusunu kavramsal açıdan değerlendirerek ulusal ve uluslararası literatürde yaşanan tanım karmaşasına olumlu yönde bir katkı sağlayabilmektir.

Bu doğrultuda çalışmada ikincil verilerden yararlanılmıştır. Veri kaynağı olarak konu ile ilgili her türlü belgeden yararlanılmıştır. Verilerin toplanmasında literatür taraması tekniğinden yararlanılmıştır. Mümkün olduğunca farklı kaynaklar kullanılarak yapılan ulusal ve uluslararası 
tarama ile çalışmaya katkı sağlaması adına kitap, ansiklopedi, dergi, lisansüstü tez, bildiri kitabı ile internet kaynaklarından yararlanılmıştır.

\section{BULGULAR}

Çalışmanın bu kısmında, literatür taraması tekniği kullanılarak elde edilen destinasyon kavramı ile ilgili ulusal ve uluslararası literatürde yer alan tanımlamalara değinilmiştir. Elde edilen bulgular çerçevesinde destinasyon kavramı ile ilgili; turistik ürün olması, çekim unsurları, özellikleri, sınıflandırması ve yönetimi konuları ile ilgili bilgilendirmelere yer verilmektedir.

\section{Destinasyon Kavramı ve Tanımı}

Birçok bileşeni barındıran destinasyon kavramı ile ilgili ulusal ve uluslararası literatürde farklı tanımlarla karşılaşılmaktadır (Minghetti, 2001:256; Haugland vd., 2011:268). Genel anlamda 'varış yeri' ifadesinin tercih edildiği turizm endüstrisinde destinasyon kavramı, yerli ve yabancı ziyaretçilerin farklı amaçlarla geçici bir süre tercih ettiği yöre, köy, kasaba, şehir, bölge, ülke hatta kıta kelimeleri yerine tercih edilmekte olup farklı çalışmalarda varış noktası, turizm bölgesi, turizm yöresi, ziyaret edilen yer, hedef bölge, turistik istasyon şeklinde de kullanılmaktadır (Lebe, 2005:1137; Vanhove, 2005:108; Akyol vd., 2018:312).

\section{Turistik Ürün Olarak Destinasyon}

Turizm; farklı alan ve bölgeler tarihi, coğrafi, kültürel ve sosyal açıdan bireylerin öğrenmesine ve anlamasına aracilık eden bir endüstridir. Destinasyon kavramı da bu endüstrinin en önemli bileşenlerinden birisidir. Rekabetin arttığı, yerli ve yabancı ziyaretçilerin daha bilinçli ve seçici davrandığı günümüz şartlarında destinasyon global bir kavram olmuştur (Suleman ve Qayum, 2019:26). Ayrıca turistik hareketler yerel, bölgesel, ulusal ve uluslararası açılardan önem kazanmış, küreselleşme faaliyetlerinin de etkisiyle turizm faaliyetlerinde çeşitlendirme ve yapılandırma ihtiyacı duyulmaya başlanmıştır (Özsezgin ve Ünlüönen, 2018:46).

Turizm destinasyonu kavramı, yerli veya yabancı ziyaretçilere sunulan farklı özelliklerdeki tabii güzellikleri ve çekicilikleri olan yerler olarak ifade edilmektedir. Turizm destinasyonu günümüz turizm endüstrisinde doğa, çevre, manzara, kültür gibi öğelerden oluşan bir birleşim şeklinde algılanan, kişinin geçici bir süre tercih ettiği, konaklama imkânı dışında tüm altyapı ve üstyapı hizmetlerinin bir arada sunulduğu turistik alandır (Akdemir ve Kırmızıgül, 2016:539).

Turizm destinasyonu, ziyaretçilerin bir yerden farklı bir yere hareketine yön veren ürün, hizmet ve tecrübelerin bir araya gelmesi ile oluşur. Doğal, kültürel ve iklimsel şartlara sahip, birbirinden farklı zenginlikleri olan, geceleme, yeme-içme, ulaşım ve iletişim gibi ihtiyaçları karşılama imkânı olan turizm destinasyonları, ziyaretçilere sunumu adına ilgili bölgeye ait etkinliklerin gerçekleşebildiği, etkin ve verimli bir marka ile imajı olma potansiyeli olan turistik alanlardır (Anuar vd., 2012:146).

Destinasyon tanımında kullanılan yöre, bölge, köy, şehir, ülke veya kıta benzeri her coğrafi alan turizm destinasyonu olarak ifade edilmemelidir. Bahsi geçen alanın turizm destinasyonu şeklinde tanımlanabilmesi için birtakım özellikleri olmalıdır (Framke, 2002:102; Hsu vd., 2004:122; Dávid ve Tözsér, 2009:81;

$>$ Ziyaretçiler seyahat amacı doğrultusunda tercih ettiği bir yer,

$>$ Ziyaretçilere ve yerel halka ürün ve hizmet sunan bir yer,

$>$ Fiziksel ve coğrafi sınırları olan bir yer,

$>$ Ziyaretçilerin ilgisini çekebilecek unsurlara sahip bir yer, 
> Mevcut ve potansiyel ziyaretçilerin düşüncelerinde imaj oluşturan bir yer,

$>$ Bütünleşik bir ürün ve hizmet sunan bir yer,

$>$ Rekabet edebilme özelliğine sahip olan bir yer.

\section{Destinasyon Çekim Unsurları}

Her endüstride olduğu gibi turizmde de rekabet ortamı özellikle tüketim bilincinin artması doğrultusunda yoğunlaşmıştır. Endüstrinin en önemli unsurlarından olan destinasyonlara yönelik rekabet ortamında ürün ve hizmetlerin farklılaşması, kalitelerinin artması ve memnuniyet sağlanması konularında en iyi imkânların oluşturulabilmesi amaçlanmaktadır (Sever ve Girgin, 2019:241). Bu yaklaşımın en önemli sebebi, yerli ve yabancı ziyaretçi beklentilerinin sadece hizmet endüstrisince değil, turizm destinasyonunun bileşenlerince de karşılanmaya çalışılmasındandır (Michalkó vd., 2015:85).

Bir destinasyonun diğerlerine göre fark yaratabilmesi, yer aldığ̣ pazardaki rekabet gücünü etkili hale getirebilecek imaj ve çekicilik unsurlarına sahip olması ile ilgilidir (Middleton vd., 2009:344). Destinasyon çekim unsurları, ziyaretçilerin beklenti, seçim ve memnuniyetlerinde oldukça önemli derecede rol oynamakta olup mevcut oldukları süre zarfında da ilgi gören ve ziyaretçi çekebilen birer turistik ürün olarak değerlendirilmektedir (Raina, 2005:102; Zengin, 2006:31; Yüncü vd., 2017:233; Karasakal, 2019:225). Destinasyon çekim unsurları Şekil 1'de yer almaktadır.

Şekil 1. Destinasyon Çekim Unsurları

\begin{tabular}{|c|c|c|c|c|}
\hline $\begin{array}{c}\text { ÇEKİCILIIKLER } \\
\text { Doğal } \\
\text { Yapay } \\
\text { Kültürel } \\
\text { Etnik }\end{array}$ & $\begin{array}{c}\text { ULAŞIM } \\
\text { Dünya trafik } \\
\text { ağına } \\
\text { kolay ulaşım }\end{array}$ & $\begin{array}{l}\text { KONAKLAMA } \\
\text { Ticari } \\
\text { Tamamlayıcı } \\
\text { Resmi olmayan } \\
\text { Özel sektör }\end{array}$ & $\begin{array}{l}\text { DESTEK HIZMETLERİ } \\
\text { Alışveriş mağazaları } \\
\text { Bankalar } \\
\text { Sağllk kuruluşları } \\
\text { Yerel halk için işletmeler }\end{array}$ & $\begin{array}{c}\text { ALTYAPI } \\
\text { Karayolu } \\
\text { Demiryolu } \\
\text { Havaalanı } \\
\text { Enerji } \\
\text { Su ve kanalizasyon } \\
\text { Diğer hizmet işletmeleri }\end{array}$ \\
\hline$\underset{\text { Ucuzl }}{\nabla}$ & & & $\underset{\text { Emniyet }}{\downarrow}$ & \\
\hline
\end{tabular}

$>$ Çekicilikler: Ziyaretçilerin seyahat olaylarında karar vermelerini direk olarak etkileyen unsurlardır. Destinasyonun çekiciliğini oluşturan özellikler; tabiatta kendiliğinden olan doğal faktörler, insan yapımı olan yapay faktörler, kültürel miras ve etkinlikler şeklinde siralanmaktadır.

> Ulaşım: Bir destinasyonun değerlendirilmesinde önemli özelliklerden biri de destinasyonun sahip olduğu ulaşım sistemidir. Birbirinden farklı çekicilik özelliğine sahip olan bir destinasyon için ziyaretçilerin önem verdiği konuların en başında ulaşım imkânı gelmektedir.

$>$ Konaklama: Konaklama, turizm endüstrisinin en temel gereksinimlerinden birisidir. Destinasyonu ziyarete gelenlerin ziyaret sürelerini artıran etkenlerden olan konaklama unsuru, ilgili işletmenin yiyecek-içecek ve diğer hizmetleri de sunması ziyaretçiler açısından destinasyonu öne çlkarabilmektedir.

> Destek Hizmetleri: Ziyaretçinin ihtiyaç duyabileceği fonksiyonları kapsayan destek hizmetleri, bireylerin destinasyondaki gündelik hayatlarının devamını sağlamaktadır. Alışveriş ünitesi, sağlık kuruluşu, banka gibi öğeler destinasyonun destek hizmetleri unsurlarıdır. 
> Altyapı: Su, kanalizasyon, haberleşme, otoyol gibi destinasyonda yer alan hizmet unsurları, ziyaretçilerin diğer unsurlardan yararlanmalarını sağlamaktadır.

Destinasyonun sahip olduğu olanaklar, ziyaretçinin türü ve elde edilecek gelir açısından önem gösteren konulardır (Pender ve Sharpley, 2005:206). Destinasyon çekim unsurlarını oluşturan çekicilik, ulaşım, konaklama, destek hizmetleri ve altyapı gibi kaynaklar, ziyaretçilerin destinasyona yönelik algı ve izlenimlerin oluşmasında etkili bir rol oynamaktadır. Bu durum destinasyona rekabet avantajı sağlayan unsurlardandır (Crouch, 2007:1).

Destinasyonların barındırdığı güvenlik, emniyet, istikrar, ucuzluk gibi özelliklerin yanında mutfak kültürü, taşıma kapasitesi, turizm gelişim planları, rekreatif etkinlikler, imaj, peyzaj ve tasarım özellikleri gibi alt başlıklar destinasyon kavramı ile ilgili ulusal ve uluslararası araştırmalarda ön plana çıkmaktadır (Prideaux, 2000:56; Russell, 2003:98; Kolb, 2006:10; Correia vd., 2007:77; Erdemir, 2018:9).

Turistik destinasyonlar ile ilgili çekim unsurları birbirini tamamlayıcı özelliklere sahip niteliklerin bir araya gelmesiyle oluşmaktadır (Şahin ve Güzel, 2018:78). Farklı araştırmacıların çalışmalarından elde edilen bulgular doğrultusunda destinasyon çekim unsurları; ulaşılabilirlik, fiziki coğrafya, tarih ve kültür, etkinlik ve aktiviteler, altyapı ve üstyapı, destekleyici hizmetler, gezi ve paket turlar, atmosfer, misafirperverlik, mutfak kültürü ve çevre biçiminde sıralanabilmektedir (Boyne vd., 2003:133; Kim, 2014:37; Demirkol ve Yozcu, 2016:76; Chang vd., 2018:3535).

Destinasyon çekim unsurları, yerli ve yabancı ziyaretçilerin turistik bölgeleri tercih etmelerinde önemli faktörler arasındadır. İlgili destinasyonların bahsi geçen unsurları barındırmasının öneminin yanı sıra, bu unsurlar koordineli ve uyumlu hareket etmeli, işbirliği içerisinde yönetilmelidir (Ağcakaya, 2019:38).

\section{Destinasyon Özellikleri}

Her endüstride olduğu gibi turizmde de rekabet ortamı özellikle tüketim bilincinin artması doğrultusunda yoğunlaşmıştır. Endüstrinin en önemli unsurlarından olan destinasyonlara yönelik rekabet ortamında ürün ve hizmetlerin farklılaşması, kalitelerinin artması ve memnuniyet sağlanması konularında en iyi imkânların oluşturulabilmesi amaçlanmaktadır (Sever ve Girgin, 2019:241). Bu yaklaşımın en önemli sebebi, yerli ve yabancı ziyaretçi beklentilerinin sadece hizmet endüstrisince değil, turizm destinasyonunun bileşenlerince de karşılanmaya çalışılmasındandır (Michalkó vd., 2015:85).

Sahip olduğu doğal, iktisadi, tarihi, sosyo-kültürel, teknolojik ve siyasi öğeleri konaklama, yemeiçme, ulaşım, rekreasyon, alışveriş gibi altyapı hizmetleri ile destekleyen destinasyonlar, yapılarındaki farklılıkların etkisiyle bazı özellikleri barındırmaktadır (Warnaby, 1998:58; Murphy vd., 2000:43; Ashword ve Voogd, 2013:8):

Ölçek: Bir ülkenin kendisi olabileceği gibi ülke içerisindeki bir köy, kasaba, şehir veya bölge de destinasyon olabilmektedir.

$>$ Bütünleşik: Destinasyon genelinde sunulan doğrudan veya dolaylı ürün ve hizmetlerin bir bütün olarak halinde sunulması gerekmektedir.

$>$ Çoklu Satış: Farklı ziyaretçi kitlelerine değişik özellikleri ön plana çıkartılan aynı destinasyonların birden fazla kez satılması mümkündür. 
> Farklı İzlenim: Bir destinasyon, yerli ve yabancı ziyaretçilerde ve paydaş gruplarında farklı tecrübe etkisi ve izlenim bırakabilir. Dolayısıyla bir destinasyonun oluşturabileceği yerel, bölgesel, ulusal ve uluslararası algı boyutları söz konusudur.

\section{Destinasyon Sinıflandırması}

Bireylerin turistik ihtiyaçlarını gidermede etkili ve turizm açısından çekiciliğe sahip bölgeler olan destinasyonların doğal ve kültürel çekicilikleri, erişilebilir özelliği, belirli bir imajı ve markası olmalıdır (González ve Falcón, 2003:720). Destinasyonların oluşumunda ve sınıflandırılmasında ekonomik, sosyo-kültürel, psikolojik ve siyasi etkenler sebebiyle farklılık gösteren birçok ölçüt rol oynamaktadır (Kavaratzis ve Ashworth, 2005:183).

Yerli ve yabancı ziyaretçilerin farklı ihtiyaç ve isteklerini karşılamaya çalışan destinasyonlar değişik özellikler taşımaktadır. Bu düşünce doğrultusunda destinasyonların farklı çeşitleri söz konusu olmaktadır (Lundgren, 1982:10; Batchelor, 1999:183; Boyd ve Singh, 2003:20; Atay, 2003:32; Studzieniecki ve Mazurek, 2007:34; Rizaoğlu, 2007:188; Özdemir, 2014:15; Karadamar ve Taşkın, 2016:3). Ulusal ve uluslararası literatürde destinasyonlara yönelik çeşitlilik ve sınıflandırma farklı başlıklar altında değerlendirilmektedir (Tablo 1):

Tablo 1. Destinasyon Sinıflandırması

\begin{tabular}{|c|c|c|c|}
\hline$\underline{\text { YAZAR(LAR) }}$ & $\underline{\mathrm{YIL}}$ & TASNIF & TÜRLER \\
\hline Faulkner ve Tideswell & 1997 & 2 & İç ve Dış Boyut (Yerliler, Destinasyonun Rolü) \\
\hline Buhalis & 2000 & 6 & Kentsel, Sahil, Dağ, Kırsal, Otantik, Egzotik \\
\hline Lew ve McKercher & 2002 & 5 & Tek, Geçişli, Çıkış, Dolaşımlı, Merkezi \\
\hline Stange ve diğ. & 2011 & 4 & Jeofiziksel-Manzara-Estetik, Ekolojik-Biyolojik, Kültür-Tarih, Rekreasyonel \\
\hline Türkay & 2014 & 7 & Şehir, Sayfiye Alan, Kırsal Alan, Dağ, Korunan Alan, Sualtı, Uzay \\
\hline Kozak & 2014 & 7 & Dinlenme, Kültür, Tarihsel, Etnik, Eğlence, İktisadi, Siyasi \\
\hline Özer & 2015 & 5 & Büyüklük, Konum, Kapsam, Faaliyet Süresi, Sahip Oldukları Çekicilikler \\
\hline Petroman & 2015 & 6 & Tarih ve Kültür, İnsan Yapısı, İş ve Konferans, Büyük-Köklü Kent, Sahil, Kırsal \\
\hline Cook ve diğ. & 2018 & 3 & Yaz, Kış, Dört Mevsim \\
\hline Tuna & 2018 & 5 & Etnik, Kültürel, Tarihi, Çevresel, Eğlence \\
\hline Kılınç & 2019 & 4 & Klasik, Doğal, İş, Kısa Kalışlı \\
\hline Bayraktaroğlu & 2019 & 4 & Yapıları, Mekânsal Özellikleri, Fiziksel Büyüklükleri, Turizm Türleri \\
\hline Güler ve diğ. & 2019 & 9 & $\begin{array}{l}\text { Temel Çekim Unsurları, Büyüklük, Politik Sınırlar, Konum, Kapsam, } \\
\text { Faaliyet Süresi, Turistin Önceliği, Turizm Türleri, Doğal veya Yapay Gelişim }\end{array}$ \\
\hline
\end{tabular}

Kaynak: Yazarlar tarafından oluşturulmuştur.

Genel anlamda sınır ve coğrafi özelliklerine göre ayrım gösteren destinasyonlar bölge, ülke, eyalet, şehir, kasaba, tematik gibi başlıklar altında değerlendirilmektedir. Turistik çekiciliklerine göre kentsel, sahil, dağ, kırsal, otantik ve egzotik başlıklarında sınıflandırılan destinasyonlar tatil deneyimlerine göre ise etnik, kültürel, tarihi, çevresel ve eğlence başlıklarına göre ayrılmaktadır (Buhalis, 2000:101; Tuna, 2018:8). Destinasyon kavramı yaz tatil, kış tatil ve dört mevsim tatil destinasyonları şeklinde de sinıflandırılırken, temel hizmetlerini sunum yaptıkları (dinlenme, kültür, tarihsel içerik, etnik turizm, eğlence, iktisadi içerikli, siyasi içerikli) alanlara göre de çeşitlilik göstermektedir (Kozak, 2014:143; Cook vd., 2018:256).

Farklı bir araştırmada destinasyonlar turizm faaliyetlerine ev sahipliği gösterdiğii (şehir, sayfiye alan, kırsal alan, dağ, korunan alan, sualtı, uzay) alanlara göre de sınıflandırılmakta olup, faaliyet sürelerine (mevsimlik, yıllık), konumlarına (yakın, uzak), büyüklüklerine (makro, mikro), sahip oldukları çekiciliklerin güçlerine (ana, ikincil) ve kapsamlarına (tekli, çoklu) göre de farklılık göstermektedir (Türkay, 2014:6; Özer, 2015:6). Destinasyonlar ayrıca jeofiziksel-manzara-estetik, ekolojik-biyolojik, kültürel-tarihi ve rekreasyonel çekiciliklere göre sınıflandırılırken (Stange vd., 2011:4), bir başka sınıflandırmada ise tek, geçişli, çıkış, dolaşımlı ve merkezi olmak üzere 
ayrılmıştır (Lew ve McKercher, 2002:612). Diğer bir araştırmada ise destinasyonlar klasik, doğal, iş ve kısa kalışlı şeklinde sınıflandırılırken (Kılınç, 2019:99), Güler ve diğerlerinin çalışmasında ise temel çekim unsurları, büyüklük, politik sınırlar, konum, kapsam, faaliyet süresi, turistin önceliği, turizm türleri ile doğal veya yapay gelişimlerine göre ayrılmıştır (2019:275).

Destinasyon çeşitlendirmesini Faulkner ve Tideswell (1997:6) iç boyut (yerliler) ve diş boyut (destinasyonun rolü) şeklinde açılarken Petroman ise (2015:341) tarih ve kültür, insan yapısı, iş ve konferans, büyük-köklü kent, sahil ve kırsal, Bayraktaroğlu ise yapılarına (doğal, insan yapımı), mekânsal özelliklerine (kapalı alan, yarı açık, açık alan), fiziksel büyüklüklerine (mini, küçük, orta ölçekli, büyük, bölge, kuşak) ve turizm türlerine göre (deniz-kum-güneş, kültürtarih) sinıflandırmaktadır (2019:27).

Destinasyon türleri ilgili araştırmalarda değişik kategori veya gruplara göre sınıflandırma yapılırken son yıllardaki turizm endüstrisinin gelişimi ve büyüme süreci dikkate alınmalı ve güncel bir şekilde sınıflandırma yapılmalıdır. Bu düşünce doğrultusunda Hudson (2008:392)'un çalışmasından da yararlanılarak güncel bir destinasyon sınıflandırılması oluşturulmaya çalışılmıştır:

> Başlıca Uluslararası Destinasyonlar: Özellikle uluslararası ziyaretçilerin ilgisini çeken Paris, New York, Milano, Londra, İstanbul gibi dünya genelinde kabul gören yerlerdir. Bu destinasyonlar 'Görülmesi Gereken Yerler' başlıklı birçok önemli gezi listelerinde yer almaktadır.

$>$ Klasik Destinasyonlar: Doğal, kültürel veya tarihi çekiciliklerin uzun süreli tatilleri teşvik ettiği destinasyonlardır. Saint-Tropez ve Lourdes şehirleri (Fransa) ile Banff Ulusal Parkı (Kanada) klasik destinasyon örnekleridir.

> Insan Yapımı Destinasyonlar, Tesisler: Ziyaretçilerin sadece belirledikleri destinasyon sınırlarını dikkate aldıkları, destinasyon dışına çıkmayı pek tercih etmedikleri yerlerdir. Her şey dâhil tatil yerleri (Karayipler, Meksika), Hilton Hawaii Köyü (Honolulu) insan yapımı destinasyonlara ve tesislere örnek olarak gösterilebilir.

> Doğal Peyzaj veya Yaban Hayatı ile Illgili Destinasyonlar: Doğal çekicilik özelliği yüksek veya ender görülen flora ve fauna türlerine ev sahipliği yapan yaşam alanlarıdır. Galapagos Adaları (Ekvador), Serengeti Yaban Hayatı Rezervi (Doğu Afrika), Kraliçe Charlotte Adaları (Kanada) bu destinasyonlara örnek gösterilebilir.

> Alternatif Destinasyonlar: Ziyaretçilerin gündelik yaşamlarını sürdürebileceği, zamansal ve mekânsal paylaşımların daha fazla olduğu yerlerdir. Tema parkları, deniz seyahatleri, West Edmonton Alş̧veriş Merkezi (Kanada) gibi büyük ve alternatifi bol tesisler alternatif destinasyon örnekleridir.

$>$ İş Turizmi Destinasyonları: Özellikle perakende ve eğlence endüstrilerinin teşvik ettiği alanlardır. Uluslararası firmaların idarecileri veya çalışanlarının uzun süre konaklamalarına ev sahipliği yapan yerler iş turizmi destinasyonlarına örnektir. Bu bölgelerdeki gelişen konukseverlik anlayışı destinasyon pazarlamasına katkı sağlayan, imaj ve marka değerini arttıran durumlardır.

> Mola Destinasyonları: Üreten ve çalışan bölgeler ile tatil yerleri arasında bulunan destinasyonlardır. Lüks konaklama nitelikleri ile güçlü yiyecek-içecek endüstrisine sahip bu destinasyonlar geniş bütçeye sahiptir. 
> Kısa Mola Destinasyonlari: Yerel, bölgesel ve ulusal etkilerinin yanı sıra uluslararası çekiciliğe de elverişli alanlardır. Niagara Şelalesi (Kuzey Amerika) kısa mola destinasyonlara örnek gösterilebilir.

$>$ Günlük Seyahat Destinasyonları: 3 S şeklinde tabir edilen (sea-sun-sand) deniz-kumgüneş üçlemesi ile ilgili istekleri karşılayan bölgesel yerlerdir. En yaygın destinasyon türüdür.

\section{Destinasyon Yönetimi}

Farklı kültür, yapı ve anlayışları olan kurum, kuruluş ve işletmelerin uyum içerisinde bulundukları zamanlar olabileceği gibi görüş farklılıklarına düşeceği durumlar da söz konusu olmaktadır. Destinasyon yönetimi, stratejik bir yönetim düşüncesi doğrultusunda karar alma ortamının oluşmasına çaba gösteren bir anlayış olup günümüz turizm pazarlama faaliyetleri kapsamında en etkili konuların başında gelmektedir (Benedetti, 2010:18).

Organizasyon, pazarlama, hizmet kalitesi ve deneyimi, bilgilendirme ve araştırma, mali durum ve girişim sermayesi, ziyaretçi yönetimi, kaynak yönetimi, kriz yönetimi gibi destinasyonu oluşturan tüm unsurların eşgüdümlü bir biçimde yönetilmesi şeklinde tanımlanan destinasyon yönetimi, ilgili destinasyonun rekabetçi gücünü artırmaya yönelik bir anlayıştır (Ritchie ve Crouch, 2010:1051).

Destinasyonlarda faaliyet gösteren veya hizmet veren paydaş gruplarının farklı çıkarları doğrultusunda birlik olmaları, ortak karar almaları, destinasyonu ilgilendiren plan ve programlar oluşturmaları destinasyon yönetim sürecinin etkili adımlarındandır (Ryglová, 2008:441; Sigala ve Marinidis, 2012:1; Tuohino ve Konu, 2014:202). Dolayısiyla turizm faaliyetlerinin destinasyon genelindeki koordinasyonu oldukça önem arz eden bir durumdur. Günümüz destinasyonlar genelinde görülen iletişim ve işbirliği sorunları, paydaş grupları arasındaki etkili ve verimli bir yönetim ihtiyacını zaruri kılmaktadır (Burnaz vd., 2017:46; Batinić, 2018:78).

Turizm endüstrisi ile ilgili tüm faaliyetlerin ve rutin işleyişin şekillenmesine sürdürülmesine katkıda bulunacak olan destinasyon yönetimi anlayışı, farklı planlama araçları, yaklaşım tarzları ve ilgili kavramların bütünleşmesi ile mümkün olacaktır (Dwyer ve Kim, 2003:402; Ojo vd., 2014:152; Conaghan vd., 2015:62). Destinasyona yönelik bir pazarlama ve hizmet anlayış1 doğrultusunda etkili ve verimli bir yönetim uygulaması neticesinde tüm paydaş gruplarının yanı sıra yerli ve yabancı ziyaretçiler için de uygun bir turizm çevresinin oluşturulması daha kolay bir hâl alacaktır. Destinasyonda faaliyet gösteren ve hizmet veren tüm paydaş gruplarının memnuniyeti, ziyaretçiye de yansıyacak, bireylerin destinasyondan daha keyifli, huzurlu ve beklentilerini karşılamış bir biçimde ayrılmasını sağlayacaktır. Bu olumlu durum, ziyaretçinin bir sonraki tercihine yansıyacak, kişinin tekrar bu destinasyonu seçmesine sebebiyet verecek (return customer) etkenlerden biri olacaktır. Bu gelişmeler, özellikle ağızdan ağıza pazarlama yönteminin destinasyon adına etkili kullanımı anlamına gelmektedir ve potansiyel ziyaretçiler açısından da dikkate alınabilecek bir durumdur.

Destinasyon yönetimi, ziyaretçilere etkin ve verimli bir destinasyon tecrübesi sunarak ürün, hizmet ve tesislerin yeterlilik ve etkinlik durumlarını değerlendiren bir yaklaşım göstermektedir. $\mathrm{Bu}$ yönetim anlayışının ana amacı, ilgili destinasyonun turizm faaliyetlerini etkin, verimli, sürdürülebilir ve bütünleşik bir yapıda gelişini sağlamaktır (Fuchs ve Weiermair, 2004:212). 
Böyle bir yaklaşım, ilgili destinasyonun tanıtım ve gelişim sürecine katkıda bulunacak, turizmle ile doğrudan ve dolaylı işbirliği içerisinde olan diğer endüstrilerin de gelişmesine yardımcı olacaktır (Sussman ve Baker, 1996:102). Bu süreç turizm aktörlerinin yanı sıra destinasyondaki diğer tüm paydaş gruplarını (kamu kurum ve kuruluşları, sivil toplum kuruluşları, özel sektör işletmeleri, yerel halk vb.) da olumlu etkileyecektir (Szabó, 2015:249; Tur vd., 2019:176).

\section{SONUÇ ve ÖNERILER}

Turistik bir ürün olması, çekim unsurlarını barındırması, farklı özelliklere sahip olması, sınıflandırma durumu, yönetim anlayışı gibi konularda farklılıklar barındıran destinasyon kavramı turizm endüstrisinin en önemli bileşenlerinden biri olup göreceli olarak ülke, bölge, şehir veya bir alana yönelik kullanılmaktadır. Özellikle tatil yöreleri veya dinlenme mekânlarına yönelik kullanımıyla ön plana çıkan destinasyon; "hedef", "yön", "taraf", "varış yeri”, "hedef noktası", "nihai gidilecek yer" gibi ifadelerle tanımlanmaya çalışılmaktadır.

Yerli ve yabancı ziyaretçilerin farklı istek ve amaçlar doğrultusunda seçimini yaptıkları yerler olan destinasyonlar karmaşık bir yapıya sahiptir. Bu karmaşık yapı, destinasyon kavramının farklı araştırmalarda değişik yazarlar tarafından türlü tanımlarla ele alınmasına sebebiyet vermektedir. Bu farklı tanımlamalar, okuyucular ve sonraki araştırmacılar için zaman zaman tanım karmaşası yaratabilmektedir.

Ortaya çıkan bu durum ve destinasyon ile ilgili kullanılan farklı ifade ile tanımlar dikkate alındığında, yerli ve yabancı turistlerin seyahatlerinin temel amacı ve yeri olan destinasyon kavramı ile ilgili ulusal ve uluslararası literatürde ortak kabul gören net bir tanımlamaya ihtiyaç duyulduğu düşünülmektedir.

Tüm veri, bulgu ve değerlendirmeler doğrultusunda, ulusal ve uluslararası literatüre katkı sağlaması amaçlanan ve çalışma neticesinde ortaya konan destinasyon tanımı ise; "yerli ve yabancı ziyaretçilerin ihtiyaçlarını (konaklama, yeme-içme, gezi, görsel, dinlenme vb.) turistik ürün ve hizmetlerle karşılayan sosyal, kültürel ve tarihi yerler olup, çekiciliği ve imajı olan veya olması muhtemel yerlerdir" şeklindedir.

Oluşturulmaya çalışılan bu tanım ile ulusal ve uluslararası literatürdeki destinasyon kavramının farklı tanımlamalarına katkı sağlanacağı düşünülmektedir. Sonraki çalışmalarda destinasyon kavramı ile ilgili her bir bileşenin ayrı ayrı ele alınması, ulusal ve uluslararası literatürde destinasyon tanımlaması denemelerine yardımda bulunacaktır. Bu durum destinasyon ile ilgili tanım farklılığına ve anlam karmaşasına olumlu anlamda etki edecek, özellikle destinasyon kavramı ile ilgili turizm araştırmalarının altyapısına bir nebze de olsa katkı sağlayacaktır.

\section{KAYNAKÇA}

Ağcakaya, H. (2019). Motivasyon Faktörlerinin Destinasyon Sadakati Üzerine Etkisini Belirlemeye Yönelik Bir Araştırma, Yayımlanmamış Yüksek Lisans Tezi, Gazi Üniversitesi, Ankara.

Akdemir, B. ve Kırmızıgül, B. (2016). Destinasyon Rekabetçiliğinin Değerlendirilmesinde Ortaya Çıkan Farklılıkları Belirlemeye Yönelik Bir Araştırma, Akademik Sosyal Araştırmalar Dergisi, 4(26): 538-553.

Akyol, C., Zengin, B., Akkaşoğlu, S. ve Ulama, Ş. (2018). Destinasyon Pazarlamasında İmaj Rolünün Üniversite Öğrencileri Tarafından Algılanması; Arhavi Meslek Yüksekokulu Örneği, MANAS Sosyal Araştırmalar Dergisi, 7(2): 637-655. 
Anuar, A. N. A., Ahmad, H., Jusoh, H. and Hussain, Y. M. (2012). Roles of Tourism System towards Development of Tourist Friendly Destination Concept, Asian Social Science, 8(6): 146-155.

Ashword, G. and Voogd, H. (2013). Can Places be Sold for Tourism? (Editor) Ashworth, G. and Goodall, B.: Marketing Tourism Places içinde (ss. 1-16) Oxford: Routledge.

Atay, L. (2003). Turistik Destinasyon Pazarlaması ve Bir Alan Uygulaması, Yayımlanmamış Doktora Tezi, Dokuz Eylül Üniversitesi, İzmir.

Batchelor, R. (1999). Strategic Marketing of Tourism Destinations, (Editor) Vellas, F. and Bécherel, L.: The International Marketing of Travel and Tourism: A Strategic Approach içinde (ss. 183-195) London: Macmillan Education.

Batinić, I. (2018). Role and Importance of Destination Management Companies in Developing Croatian Tourist Destinations, Journal of Process Management-New Technologies, 6(2), 78-83.

Bayraktaroğlu, E. (2019). Destinasyon Değerinin Kuramsal Altyapısının Oluşturulması, Yayımlanmamış Doktora Tezi, Anadolu Üniversitesi, Eskişehir.

Benedetti, J. (2010). The Competitiveness of Brazil as a Dutch Holiday Destination, Unpublished Master Thesis, Breda University of Applied Science, Breda.

Boyd, W. S. and Singh, S. (2003). Destination Communities: Structures, Resources and Types, (Editor) Singh, S., Timothy, D. J. and Dowling, R. K.: Tourism in Destination Communities içinde (ss. 19-33) UK: CABI Publishing.

Boyne, S., Hall, D. and Williams, F. (2003). Policy, Support and Promotion for Food-Related Tourism Initiatives, Journal of Travel \& Tourism Marketing, 14(3-4): 131-154.

Buhalis, D. (2000). Marketing the Competitive Destination of the Future, Tourism Management, 21: 97-116.

Burnaz, E., Kurtuldu, S. H. and Akyüz, M. A. (2017). An Organization Structure Suggestion of National Destination Management Organizations for Turkey, Global Journal of Economics and Business Studies, 6(13): 46-63.

Chang, M., Kim, H. J. and Kim, D. (2018). The Effect of Food Tourism Behavior on Food Festival Visitor's Revisit Intention, Sustainability, 10(10): 3534-3548.

Conaghan, A., Hanrahan, J. and McLoughlin, E. (2015). The Sustainable Management of a Tourism Destination in Ireland: A Focus on County Clare, Advances in Hospitality and Tourism Research, 3(1): 62-87.

Cook, A. R., Hsu, C. and Taylor, L. L. (2018). Tourism: The Business of Hospitality and Travel. (6. Edt.). Boston: Pearson.

Correia, A., Valle, P. O. and Moço, C. (2007). Modeling Motivations and Perceptions of Portuguese Tourists, Journal of Business Research, 60(1): 76-80.

Crouch, G. I. (2007). Modelling Destination Competitiveness; A Survey and Analysis of the Impact of Competitiveness Attributes, Technical Report, Australia: CRC for Sustainable Tourism Pty Ltd.

Dávid, L. and Tözsér, A. (2009). Destination Management in Hungarian Tourism. 4. Aspects and Visions of Applied Economics and Informatics Congress, 26-27 Mart 2009, Halle: Budapest. s: 81$84)$.

Demirkol, Ş. ve Yozcu, S. (2016). Destinasyon Markalaşması, (Editör) Demirkol, Ş.: Turizmde Markalaşma (ss. 71-121) İstanbul: Değişim Yayınları. 
Dwyer, L. and Kim, C. (2003). Destination Competitiveness: Determinants and Indicators, Current Issues in Tourism, 6(5): 369-414.

Erdemir, B. (2018). Sürdürülebilir Turizm Kapsamında Destinasyonların Fiziksel ve Psikolojik Taşıma Kapasitesi Analizi: Pamukkale Hierapolis Ören Yeri Örneği, Yayımlanmamış Yüksek Lisans Tezi, Balıkesir Üniversitesi, Balıkesir.

Faulkner, B. and Tideswell, C. (1997). A Framework for Monitoring Community Impacts of Tourism, Journal of Sustainable Tourism, 5(1): 3-28.

Framke, W. (2002). The Destinastion as a Concept: A Discussion of the Business-Related Perspective versus the Socio-Cultural Approach in Tourism Theory, Scandinavian Journal of Hospitality and Tourism, 2(2): 92-108.

Fuchs, M. and Weiermair, K. (2004). Destination Benchmarking: An Indicator-System's Potential for Exploring Guest Satisfaction, Journal of Travel Research, 42(3): 212-225.

González, A. M. and Falcón J. M. (2003). Competitive Potential of Tourism in Destinations, Annals of Tourism Research, 30(3): 720-740.

Güler, O., Ekici, R., Güven, A. ve Özdemir, G. (2019). Turizmde Destinasyon Yönetimi, (Editör) Çakıcı, A. C.: Kavramlar ve Örneklerle Genel Turizm içinde (ss. 273-299) Ankara: Detay Yayıncılık.

Haugland, S. A., Grønseth, H. N. B. and Aarstad, J. (2011). Development of Tourism Destinations: An Integrated Multilevel Perspective, Annals of Tourism Research, 38(1): 268-290.

Hsu, C. H. C., Wolfe, K. and Kang, K. S. (2004). Image Assessment for a Destination with Limited Comparative Advantages, Tourism Management, 25: 121-126.

Hudson, S. (2008). Tourism and Hospitality Marketing: A Global Perspective. London: Sage Publications.

Karadamar, A. A. ve Taşkın, Ç. (2016). Destinasyon Markalaması. Bursa: Dora Basım-Yayın Dağıtım.

Karasakal, S. (2019). Destinasyon Çekicilikleri Üzerine Bir Literatür Taraması: Türkiye, İspanya ve Yunanistan Karşılaştırması, Selçuk Üniversitesi Sosyal Bilimler Meslek Yüksekokulu Dergisi, 22(1): 225-245.

Kavaratzis, M. and Ashworth, G. J. (2005). City Branding: An Effective Assertion of Identity or a Transitory Marketing Trick? Place Branding, 2(3): 183-194.

Kılınç, O. (2019). Destinasyon Türleri, (Editör) İçöz, O. ve Uysal, M.: Turizm Ansiklopedisi - Türkiye: Turizm ve Ağırlama Endüstrisinin Temel Kavramları içinde (ss. 99-100) Ankara: Detay Yayıncllık.

Kim, J. H. (2014). The Antecedents of Memorable Tourism Experiences: The Development of a Scale to Measure the Destination Attributes Associated with Memorable Experiences, Tourism Management, 44: 34-45.

Kolb, B. M. (2006). Tourism Marketing for Cities and Towns: Using Branding and Events to Attract Tourism. Boston: Elsevier.

Kozak, N. (2014). Turizm Pazarlaması. (6. Baskı). Ankara: Detay Yayıncılık.

Lebe, S. S. (2005). Possible Way of Sustainable Tourism Development in Rural Areas by Innovating its Organisation through Network Management, Kybernetes: The International Journal of Systems \& Cybernetics, 35(7/8): 1136-1146. 
Lew, A. A. and McKercher, B. (2002). Trip Destinations, Gateways and Itineraries: The Example of Hong Kong, Tourism Management, 23: 609-621.

Lundgren, J. O. J. (1982). The Tourist Frontier of Nouveau Quebec: Functions and Regional Linkages, Tourist Review, 37(2): 10-16.

Michalkó, G., Irimiás, A. and Timothy, D. J. (2015). Disappointment in Tourism: Perspectives on Tourism Destination Management, Tourism Management Perspectives, 16: 85-91.

Middleton, T. C. V., Fyall, A., Morgan, M. and Ranchhod, A. (2009). Marketing in Travel and Tourism (4. Edt.), Oxford: Elsevier Ltd.

Minghetti, V. (2001). From Destination to Destination Marketing and Management: Designing and Repositioning Tourism Products, International Journal of Tourism Research, 3: 253-259.

Murphy, P., Pritchard, M. P. and Smith, B. (2000). The Destination Product and its Impact on Traveller Perceptions, Tourism Management, 21: 43-52.

Ojo, S. F., Lattimore, C. and Nair, V. (2014). A Framework for Rural Tourism Destination Management and Marketing Organisations, Procedia - Social and Behavioral Science, 144: 151-163.

Özdemir, G. (2014). Destinasyon Yönetimi ve Pazarlaması. Ankara: Detay Yayıncılık.

Özer, S. U. (2015). Destinasyon Kavramı, Özellikleri ve Yönetimi, (Editör) Yüncü, D.: Destinasyon Yönetimi içinde (ss. 2-18) Eskişehir: Anadolu Üniversitesi Yayınları.

Özsezgin, İ. ve Ünlüönen, K. (2018). Destinasyon İmajının Markalaşmaya Etkisi: Bodrum Örneği. Journal of Recreation and Tourism Research, 5(4): 45-62.

Pender, L. and Sharpley, R. (2005). The Management of Tourism. London: Sage Publications.

Petroman, C. (2015). Typology of Tourism Destinations, Scientific Papers: Animal Science and Biotechnologies, 48(1): 338-342.

Pike, S. (2004). Destination Marketing Organisations. Amsterdam: Elseiver Ltd.

Prideaux, B. (2000). The Role of the Transport System in Destination Development, Tourism Management, 21: 53-63.

Raina, A. K. (2005). Ecology, Wildlife and Tourism Development: Principles, Practices and Strategies. New Delhi: Sarup \& Sons.

Rızaoğlu, B. (2007). Turizm Pazarlaması. Ankara: Detay Yayıncılık.

Ritchie, B. and Crouch, G. I. (2010). A Model of Destination Competitiveness/ Sustainability: Brazilian Perspectives, RAP - Rio de Janeiro, 44(5): 1049-1066.

Russell, B. (2003). Agri-Tourism Workbook. Portland: The Agri-Business Council of Oregon.

Ryglová, K. (2008). Destination Management, Agricultural Economics, 54(9): 440-448.

Sever, P. ve Girgin, G. K. (2019). Turistlerin Restoran Deneyimleri ile Destinasyonu Tekrar Ziyaret Etme Niyeti Arasındaki İlişkinin Belirlenmesi: İstanbul Örneği, Gastroia: Journal of Gastronomy and Travel Research, 3(2): 241-263.

Sigala, M. and Marinidis, D. (2012). E-Democracy and Web 2.0: A Framework Enabling DMOS to Engage Stakeholders in Collaborative Destination Management, Tourism Analysis, 17: 1-16.

Stange, J., Brown, D., Hilbruner, R. and Hawkins, D. E. (2011). Tourism Destination Management Achieving Sustainable and Competitive Results. Washington: International Institute for Tourism 
Studies. [Online] https://www.usaid.gov/sites/default/files/documents/2151/DMOworkbook 130318.pdf [Erişim Tarihi: 21.05.2019]

Studzieniecki, T. and Mazurek, T. (2007). How to Promote a Cross-Border Region as a Tourism Destination - The Case Study of the Bug Euroregion, Tourism Review, 62(1): 34-38.

Suleman, R. and Qayum, B. (2019). Religion and Islamic Tourism Destinations, (Editor) Jamal, A., Raj, R. and Griffin, K.: Islamic Tourism: Management of Travel Destinations içinde (ss. 26-37) Croydon: CAB International.

Sussman, S. and Baker, M. (1996). Responding to the Electronic Marketplace Lessons from Destination Management Systems, International Journal of Hospitality Management, 15(2): 99-112.

Szabó, D. R. (2015). Sustainable Tourism Destination Management Strategies: Using the EVIDENCES Model for Evaluating TDM Tenders, (Editor) Karlovitz, J. T.: Some Current Issues in Economics içinde (ss. 249-258) Komarno: Interantional Research Institute.

Şahin, İ. ve Güzel, F. Ö. (2018). Destinasyon Deneyimi Bileşenleri: Antalya ve İstanbul Destinasyonları Üzerinde Karşılaştırmalı Bir Araştırma, Anatolia: Turizm Araştırmaları Dergisi, 29(1): 77-89.

Şengül, S., Yılmaz, Ö. ve Eryılmaz, B. (2018). Stratejik Boyutuyla Destinasyon Pazarlaması. İstanbul: Değişim Yayınları.

Tinsley, R. and Lynch, P. (2001). Small Tourism Business Networks and Destination Development, International Journal of Hospitality Management, 20: 367-378.

Tuna, S. (2018). Tüketicilerin Destinasyon Seçimini Etkileyen Faktörlerin Araştırılması, Yayımlanmamış Yüksek Lisans Tezi, Adnan Menderes Üniversitesi, Aydın.

Tuohino, A. and Konu, H. (2014). Local Stakeholders' Views about Destination Management: Who is Leading Tourism Development? Tourism Review, 69(3): 202-215.

Tur, A. A, Medina, P. J. and Casado, N. S. (2019). Can Personal Values Modulate the Perception of Tourism Impacts by Local Population?: Testing for the Role of Product Identity in a Mining Tourism Destination, (Editor) Cerro, A. M., Mogollón, J. M. and Fernández, J. A.: Best Practices in Hospitality and Tourism Marketing and Management içinde (ss. 159-180) Cham: Springer International Publishing AG.

Türk Dil Kurumu. (2019). Güncel Türkçe Sözlük, sozluk. gov.tr [Erişim Tarihi: 29.07.2019].

Türkay, O. (2014). Destinasyon Yönetimi: Yönetimbilim Bakış Açısıyla İşlevler, Yaklaşımlar ve Araçlar. Ankara: Detay Yayıncilı.

Vanhove, N. (2005). The Economics of Tourism Destinations. Oxford: Elsevier.

Wang, Y. (2011). Destination Marketing and Management: Scope, Definition and Structures, (Editor) Wang, Y. and Pizam, A.: Destination Marketing and Management: Theories and Applications içinde (ss. 1-20) London: CAB International.

Warnaby, G. (1998). Marketing UK Cities as Shopping Destinations: Problems and Prospects, Journal of Retailing and Consumer Services, 5(1): 55-58.

Yüncü, D., Kantar, M. Y., Aktaş, G. S. ve Sezerel, H. (2017). Turist Çekicilikleri ve Turist Akışı Arasındaki İlişkilerin Mekânsal Bağımlılığa Dayalı Olarak İncelenmesi, Social Sciences (NWSASOS), 12(4): 232-247.

Zengin, B. (2006). Turizm Coğrafyası. (2. Baskı), İstanbul: Değişim Yayınevi. 